\title{
FILSAFAT IKHWAN ASH-SHAFA
}

\author{
M. SamsulHady
}

Fakultas Tarbiyah Universitas Islam Negeri (UIN) Malang Jalan Gajayana No. 50 Malang 65144 Telp. 0341-551354 Faks.0341-572533 e-mail: hady_tot2@yahoo.com

\begin{abstract}
Brethren of Purity (Ikhwan al-Safa) is a group of philosophers in medieval Islamic history. There are some opinions of their origin. Brethren of Purity emerge in Basrah in tenth century, but their religious and political affiliation is still in mystery. They declared themselves as opposants of any chastity, impurity, or opacity. Their thoughts compiled in an encyclopedia containing of fifty two treaties (epistles), titled al-Rasa'il Ikhwan al-Safa wa Khullan al-Wafa. Al-Rasa'il extensively surveys a huge range of subjects ranging from music to magic. They are didactic in tone and highly ecletic in content, providing both paedagogical and culture mirror of their Age and its diverse philosophies and creeds. It's neatly devided into four main parts: fourteen focused on mathematical sciences, seventeen deal with the natural sciences, and eleven conclude the latest four-vulume Arabic edition by concentrating on what are called metaphysic or theological sciences. Therefore, al-Rasail is still debatible of its origin, one claims to the writing of Ali bin Abi Talib, the fourth Muslim Caliph (d. 40/661), or the writing of the sixth Shi'ite Imam, Imam Ja'far al-Sadiq. The encyclopaedia aspires to encompass all knowledge, from all sources, and to give meaning to the struggles of the human race. One of all amazing notions of the Brethren of Purity is a numerical symbolism as applied to explain qualitative correspondence of three principal beings: God as The Creator, universe, and human being.
\end{abstract}

Ulul Albab, Vol. 8 No. 2, 2007 
Key words: kosmologi, filsafat

\section{Pendahuluan}

Berbeda dengan kebanyakan filosof muslim yang pada masanya muncul sebagai the single figure, Ikhwan al-Shafa membentuk kelompok yang menyatukan berbagai figur filosof, dengan berbagai latar-belakang dan keahlian filo-saintifik. Filosof-filosof seperti Al-Kindi, al-Farabi, Ibnu Sina, al-Razi, al-Ghazali, al-Amiri, Ibnu Miskawaih di Wilayah Islam Timur, atau Ibnu Masarrah, Ibnu Bajah, Ibnu Thufail, Ibnu Rusyd, Ibnu Sab'in, dan Ibnu Khaldun di bagian Barat, mereka muncul sebagai diri mereka sendiri, (dan karenanya mengintrodusir pemikiran-pemikiran individual mereka). Ikhwan al-Shafa muncul di Wilayah Timur dalam sebuah perkumpulan atau organisasi yang bersifat rahasia. Kerahasiaan ini dapat mengindikasikan bahwa kelompok cendekiawan ini memiliki pemikiran-pemikiran yangsedikit atau banyak-kurang lazim di lingkungannya, atau dipandang kurang selaras-mungkin karenarumitatau karena berseberangan-dengan trend perkembangan dan kehendak khalayak di sekitar mereka.

Pemikiran-pemikiran mereka, sebagaimana dikompilasikan dalam sebuah ensiklopedi yang diberi nama al-Rasa'il, karena sifatnya yang filosofis, tampak begitu mendasar dan rumit. Namun, seperti halnya para filosof individual lainnya, pusat perhatian pemikiran mereka menyangkut maknamakna laten dari keseluruhan realitas. Ikhwan al-Shafa melaksanakan pertemuan-pertemuan ilmiah untuk membahas berbagai persoalan, di samping juga melakukan berbagai ritual yang mereka pandang sebagai aktivitas yang menyelaraskan jiwa dan memenuhi keyakinan-keyakinan mereka.

Ikhwan al-Shafa, bagaimanapun, telah berhasil mengungkapkan misteri-misteri tersembunyi berbagai realitas fenomenal dan interrelasinya pada tataran yang paling dalam di pusat eksistensi. 


\section{Asal Usul Ikhwan al-Shafa}

Banyak spekulasi mengenai asal usul Ikhwan al-Shafa ini, terutama karena sifat organisasi dan pergerakannya bersifat laten. Ikhwan al-Shafa ditengarai sebagai kelompok rahasia yang beranggotakan para ilmuan, yang pemikirannya bercorak keagamaan, politik, dan filosofis (al-Mawsu'ah alArabiyyah al-Maysarah, 1996: 66); para filosof dan ensikolopedis yang mengadakan pertemuan-pertemuan rahasia untuk membahas pemikiranpemikiran mereka (Qadir, 1991:58). Ikhwan al-Shafa diperkirakan muncul di Bashrah pada masa Bani Buwaih pada abad ke 10, yakni ketika pemerintahan Islam di Baghdad mengalami disintegrasi yang ditandai oleh lahirnya dinasti-dinasti kecil yang independen.

Latar belakang terbentuknya Ikhwan al-Shafa serta motivasi mereka sulit dipastikan, apakah politis, keagamaan, ataukah filsafat. Ada yang menyatakan Ikhwan al-Shafa adalah sempalan Syiah Ismailiyah dalam persoalan politik dan keagamaan (Qadir: 1991:66), yang telah begitu jauh terlibat propaganda polivik rahasia, terutama para propagandis Qaramithah; namun, mereka kemudian menambahkan wacana keilmuan dan filsafat ke dalam pergerakannya (Fakhry: 1983: 236; Hitti, 1950:449-5; Ensiklopaedia of Islam, 1993: Qamatians).

Pengaitan Ikhwan al-Shafa kepada Syiah Ismailiyahberargumen bahwa Rasa'il, ensiklopedi yang mereka susun, dipakai secara luas di kalangan Ismailiyah, terutama di Yaman, dan karena karya itu diterima oleh Ismailiyyah sebagai bagian dari argumen keagamaan mereka, terutama dalam faham-faham esoteris mereka. Tidak mengherankan jika kemudian para cendekiawan muslim dan non-muslim mengklaim kitab itu ditulis oleh kelompok Ismailiyah. Salah satu dari para cendekiawan itu adalah A. Tamir, yang menyatakan Rasa'il berasal dari Syiah Ismailiyah, karena jumlahnya sama dengan nilai bilangan nama Abdullah bin Muhammad yang menyusun kitab itu-menurut versi penguasa Ismailiyah. Bahkan Rasa'il dinyatakan sebagai filsafat Ismailiyah.

Ulul Albab, Vol. 8 No. 2, 2007 
H.F. Hamdani, seorang intelektual Ismailiyah, menolak Ismailiyah sebagai pengarang Rasa'il , kendatipun mengakui peranan Rasa'il dalam misi Ismailiyah di Yaman. A.L. Tibawi menyatakan bahwa menghubungkan Ikhwan al-Shafa kepada Ismailiyah adalah persoalan baru. Baginya, Ikhwan al-Shafa adalah simbol gerakan Syiah, ketika al-Ghazali memperkenalkan gerakan Sunni dalam satu sintesis (Nasr, 1978; 27-8). Tibawi dalam tulisannya yang lain (dalam Islamic Quarterly, 1956, 3:148) menyebutkan bahwa yang sering menghubungkan Ikhwan al-Shafa dengan Ismailiyah adalah para penulis Barat, seperti Cassanova, Goldziher, MacDonald, Lane-Pool, Massignon, dan Ivanov. Henry Corbin menyebut Ikhwan al-Shafa sebagai kelompok terdidik yang kemunculannya bersamaan dengan munculnya sekte Ismailiyah.

Masa kemunculan Ikhwan al-Shafa ditandai pula oleh pemerintahan yang kebijakannya bersifat intoleran terhadap perbedaan agama atau faham (Fakhry, 236, Hitti, 461-62). Masa kemunculan Ikhwan al-Shafa ditandai oleh keadaan yang menekan rasionalisme, mengutuk para filosof sebagai penganut bid'ah, perusak aqidah agama. Para penguasa seperti Mutawakkil (Abbasiyah, 232-247) dan al-Mustakfi (Bani Buwaih, 234), mendukung fuqaha dan menyerang para rasionalis seperti kaum Mu'tazilah (Departemen Agama, 1993:389-92). Ikhwan al-Shafa lebih ingin memurnikan syariat Islam yang dianggapnya telah tercemar oleh ajaran-ajaran di luar Islam, dan untuk membangkitkan kembali rasa cinta ilmu pengetahuan dan di kalangan umat Islam. Untuk tujuan itu dibutuhkan filsafat. Maka, Ikhwan al-Shafa mempelajari filsafat Yunani, Persia, India dan lain-lain, kemudian dipadukan dengan agama (IAIN Syarif Hidayatullah, 1971:413, 10:163).

Pandangan lain menyebutkan bahwa Ikhwan al-Shafa adalah penerus kaum Mu'tazilah, yang terutama bertujuan merukunkan kembali ilmu pengetahuan dan agama, menyelaraskan hukum Islam dengan filsafat Yunani, serta mensintesiskan semua ilmu pengetahuan dalam bentuk ensiklopedi, kitab yang memperkenalkan faham-faham yang bergulir di kalangan cendekiawan terkemuka di kekhalifahan Abbasiyah saat itu (Qadir, 1991:58-9); Brown, 1951: 292-3). Ibnu Qifti mengklaim Ikhwan al-Shafa

Ulul Albab, Vol. 8 No. 2, 2007 
sebagai pengikut Mu'tazilah yang menggunakan pendekatan rasional, dan Ibnu Taymiyah menyebutnya pengikut Nusairiyah yang menyempal dari kelompok rasionalis (Nast, 1978:25; al-Qifti dalam al-Akhbar al-Hukama', 1909: 58-62). Al-Awa menganalisis, terlepas dari kedekatannya kepada kelompok mana pun, menurutnya Ikhwan al-Shafa adalah Post-Mu'tazilah. Rasa'il adalah kombinasi pandangan-pandangan Mu'tazilah dan Syiah (Nasr, 1978: 28). S. Pins menyimpulkan dari analisisnya atas corak pemikiran Ikhwan al-Shafa dalam Rasa'ilnya, bahwa Ikhwan al-Shafa menuturkan kesenjangan antara dua pemikiran, yakni Syiah dan teori politik al-Farabi (S. Pins, "Some Problems of Islamic Philosophy", (Islamic Quarterly, 11, 1937: 71).

Walaupun merupakan sempalan Ismailiyah dan pengikut Mu'tazilah, Ikhwan al-Shafa bukanlah definit penganut pemikiraan dua kelompok itu. (Dengan Islaimiyah berbeda), Ikhwan al-Shafa menolak imamah yang geneologis dan imam yang tersembunyi (hidden iman). Dengan Mu'tazilah, Ikhwan al-Shafa berbeda berbeda karena percaya karena kelak di akhirat Tuhan akan menampakkan diri dan dapat dilihat dengan mata kepala, dan juga karena sikap pertentangannya dengan Mutakallimun, ahli-ahli kalam (Fakhry, 1983: 59; Encyclopaedia of Islam, 1071, Nasr, 27) bahkan, Ikhwan al-Shafa bukanlah sebuah sekte ataupun agama. Ikhwan al-Shafa menasihatkan pengikumya untuk tidak memandang rendah siapapun dan agama apapun. Agama dan pandangan Intelektual mereka mencakup semua agama dan semua ilmu pengetahuan. Ikhwan al-Shafa berpikir liberal, bernakat dari sektarian. Meningkat kepada intelektual, kemudian berbicara denagan bahasa akal universal. Ikhwan al-Shafa bersifat lebih kosmologis dan simbolik daripada rasionalistik, sehingga harus dikeluarkan dari mazhab Mu'tazilah, juga dari pengikut Aristoteles, kelompok Masysya'iyun atau Masysya'un (Nasr, 1978:35).

Cendekiawan yang termasuk ke dalam kelompok Ikhwan al-Shafa, sekaligus terlibat dalam penyusunan kitab Rasa'il , juga merupakan persoalan yang masih diperdebatkan oleh banyak pengamat. Menurut sumber-sumber lama, Rasa'il dikarang oleh kelompok cendekiawan dari Basrah. Beberapa

Ulul Albab, Vol. 8 No. 2, 2007 
pandangan mengenai tokoh-tokoh yang diklaim menyusun Rasa'il dikemukakan berikut ini:

1. Ibnu al-Qifti, dalam al-Akhbar al-Hukama', mengutip Ibnu Hayyan alTawhidi, pengarang Rasa'il adalah Abu Sulayman Muhammad Ibnu Ma'syar al-Basti, Abu Hasan Ali Ibnu Harun al-Zanjani, Abu Ahmad al-Mihrajani, Awfi, dan Zaid ibnu Rifa'iy.

2. Shahwazuri, dalam Nuzhat l-Arwah, menyebut pengarang Rasa'il terdiri dari Abu Sulaiman al-Tawhidi, Muhammad Ibnu Mas'ud al-Basti (alMuqaddasi), Abu Hasan Ali Ibnu Wahrun al-Sabi', Abu Ahmad alNahrajuni, Awfi al-Basri, dan Zaid Ibnu al-Rifa'iy.

3. Abu Ahmad al-Tawhidi menyebutkan bahwa Abu Abdullah alSya'dan, seorang Wazir yang terbunuh tahun 273/985 mempunyai sekelompok sarjana dalam melaksanakan kewazirannya, terdiri dari Ibnu Zar'ah (331/942-389/1007), Misykawaih al-Razi (w. 421/1029), Ibnu al-Wafa' al-Buzjani, Abu al-Qasim al-Ahwazi, Abu Said Bahrain, Ibnu Sahuhayah, Ibnu Bakr, Ibnu Hajjaj al-Shair, Shukh Shi'i (w. 391/1000), dan Abid al-Khatib yang pandangan-pandangannya dikompilasi menjadi Rasa'il .

4. A.L. Tibawi menyatakan Rasa'il ditulis oleh Ali bin Abi Thalib, alGhazali, Hajjaj, Imam Ja'far al-Shadiq, atau para dai Ismailiyah. Oleh beberapa tokoh Ismailiyah di Yaman, Rasa'il ditulis sebagai al-Qur'an setelah al-Qur'an, yaitu al-Qur'an Imamah (Nasr, 1978:27-27).

Kitab Rasa'il (lengkapnya: Rasa'il Ikhwan al-Shafa wa Khullan al-Wafa') merupakan tuangan pemikiran Ikhwan al-Shafa yang dapat dipandang lengkap. Ini konsisten dengan pendiriannya untuk mengambil semua hikmah atau kebijaksanaan (wisdom, wages), termasuk ilmu pengetahuan, dari semua sumber, semua agama, semua aliran pemikiran, dan semua bangsa (IAIN Syarif Hidayatullah: 413). Ikhwan al-Shafa berpendapat bahwa kebenaran itu satu, namun bukan milik orang tertentu. Kebenaran diberikan kepada umat Kristen, Islam, orang kulit hitam atau yang berkulit putih (Nasr: 
1978:32). Oleh karena itu, pemikiran Ikhwan al-Shafa bersifat eklektik, diambil dari sumber-sumber yang beragam dan dipadukan menuju tujuan akhir. Kitab ini merupakan kumpulan risalah sejumlah 52 buah, termasuk di dalamnya satu risalah yang merangkum keseluruhan isi Rasa'il, yaitu alRisalah al-Jami'ah. Selanjutnya Rasa'il dibukukan dalam empat jilid. Isi Rasa'il diorganisasikan sebagai berikut: 14 risalah tentang matematika, 17 risalah mengenai ilmu alam, 10 risalah mengenai psikologi, dan 11 risalah tentang ilmu ketuhanan dan keakhiratan (IAIN: 413-4). Ilmu pengetahuan yang tertuang di dalamnya diklasifikasikan menjadi: (1) sains primer (riyadhiyah), meliputi sembilan macam ilmu, mulai ilmu membaca, menulis, hingga sejarah dan biografi, (2) sains agama (al-Syari'ah al-wadhhiyah), meliputi enam ilmu, mulai ilmu kewahyuan hingga penafsiran mimpi, dan (3) sains filosofis (al-falsafiyah al-haqaqah), meliputi matematika hingga teologi (lihat lebih rinci pada Nasr: 1978:42-3). Pengaruh Rasa'il tampak cukup berarti terhadap para pemikir sezamannya dan beberapa abad kemudian. Saat itu, Rasa'il telah diterjemahkan ke dalam bahasa Persi, Turki, Hindustan (India), sehingga begitu populer pada abad 10, yang gagasan-gagasan kosmologis dan metafisiknya tergambar dengan jelas dalam karya-karya cekdekiawan saat itu, hingga beberapa abad berikutnya.

Organisasi Ikhwan al-Shafa telah tersebar pada abad $14 \mathrm{H}$ di mana Abu Ala al-Masuni menemukan cabangnya di Baghdad antara tahun 393 dan 400. Rasa'il dibaca dan dipakai oleh Ibnu Sina, al-Ghazali, dan Ibnu Haytham, dan ortodoksinya didebat oleh Ibnu Taymiyah. Orang-orang Druz dan Assasin juga membaca Rasa'il secara luas, begitu pula orang Ismailis Yunani sangat menghargainya. Rasa'il diperkenalkan di Spanyol oleh alMajridi dan al-Kirmani dan berpengaruh terhadap dua pengarang tersohor dari Maghribi, Muhyiddin Ibnu Arabi dan Ibnu Khaldun (Nasr: 36).

Tujuan gerakan tampak dari muatan Rasa'il nya yang bersifat filosofis, keagamaan, bahkan politis (al-Mawsu'ah al-Arabiyah al-Maysarah: 66). Tujuan filosofis dan keagamaan adalah mengkombinasikan agama dan filsafat: membersihkan syariah dari kotoran dengan filsafat. Tujuan Ikhwan al-Shafa tampak juga bersifat edukasional, yaitu menyempurnakan fakultas-

Ulul Albab, Vol. 8 No. 2, 2007 
fakultas laten manusia sehingga dapat mencapai keselamatan dan kebebasan spiritual. Sepanjang karyanya Ikhwan al-Shafa menekankan bahwa manusia adalah narapidana dunia, dan dengan pengetahuan manusia dapat membebaskan diri. Semua ilmuyang mereka bahas, tidak hanya bertujuan murni teoretis atau intelektual, dan aplikasinya, tetapi juga untuk menyadarkan manusia akan harmoni dan keindahan luar biasa alam semesta, dan menyadarkan pentingnya melampaui wujud material. Untuk mencapai hal itu Ikhwan al-Shafa merangkum nilai-nilai pendidikan dari banyak bangsa (Nasr, 1978: 30).

Tujuan yang bersifat edukasional dan cenderung mengarah kepada mistisime, ini dapat dilihat pada konsepnya tentang manusia ideal dan tentang peringkat anggota perkumpulan Ikhwan al-Shafa itu sendiri. Manusia ideal dan sempurna moralnya, menurut Ikhwan al-Shafa, adalah keturunan Persia Timur, beragama Arab (Islam), berpendidikan Irak, yakni Babilonia, kecerdikan Yahudi, berperilaku murid-murid Yesus, seperti salihnya para biarawan (rahib) Suriah, berilmu pengetahuan Yunani, berkemampuan interpretasi segala misteri orang India, dan terakhir serta terpenting adalah suci (Sufi) dalam keseluruhan hidup spiritualnya (Nasr, 1978:3; dari T.J. De Boer, The History of Philosophy in Islam, 1933:95; Rasa'il, II:279). Sedangkan peringkat keanggotaan Ikhwan al-Shafa adalah:

1. Al-Abrar al-Ruhama'. Mereka memiliki kesucian fisik, pandai dalam konsepsi dan asimilasi. Disebut saudara yang salih dan penyayang, minimal berumur 15 tahun.

2. Al-Akhyar dan al-Fudhali, tingkatan filosofis, meliputi para pemimpin politis, yakni kelompok orang terdidik dan religius, dan usia mereka minimal 30 tahun. Mereka memiliki kesabaran dan kepedulian terhadap sesama manusia.

3. Al-Fudhala' al-Kiram, tingkatan raja dan sulthan. Mereka memiliki kemampuan menghadapi perang dan pemberontakan secara terang dan lembut dengan maksud mencapai keselamatan, menunjukkan kekuatan 
hukum ilahiah. Dicapai dalam usia minimal 40 tahun. Mereka disebut sebagai bangsawan terdidik dan bijaksana.

4. Tingkat tertinggi (al-Kamal), memperoleh wahyu dan ma'rifah, yaitu tingkatan malaikat, sebagai persiapan meningkat ke taraf ilahiah, dicapai dalam usia minimal 50 tahun, termasuk di sini adalah Ibrahim, Yusuf, Yesus, Muhammad, Socrates, dan Pythagoras (Nasr, 1978:31; Fakhry, 1983:238).

Sebagai organisasi, Ikhwan al-Shafa melakukan upcara-upacara kebaktian menurut maksud-maksud tertentu. Kebaktian filosofis Ikhwan al-Shafa dilakukan tiga malam setiap bulan: di awal, pertengahan, dan kadang-kadang antara tanggal 25 sampai akhir bulan. Kebaktian malam pertama adalah orasi personal, pertengahannya membaca teks kosmik di bawah sinar bintang-bintang menghadap ke bintang kejora, dan malam ketiga adalah hymne filosofis (bertema metafisik dan metakosmik) berupa sembahyangnya Plato, doanya Nabi Idris, dan Mazmur sucinya Aristoteles. Adapun pesta filosofis selama setahun, ketika masuknya matahari ke dalam tanda-tanda Ram, Cancer, dan Balance. Ikhwan al-Shafa menghubungkan pesta-pesta itu dengan Idul Fithri, Idul Adha, dan Idul Ghadir pada 18 Zulhijjah, hari pelantikan Ali Ibnu Abi Thalib oleh Nabi sebagai penggantinya pada Ghadir Khum (tempat dimana menurut kepercayaan syi'ah nabi memberikan wasiat kepada Ali tentang suksesi kekhalifahan. Dengan dasar ini (Ghadir Khum), kaum syi'ah mengklaim yang berhak menjadi khalifah pertama adalah Ali, sebuah hari raya Syiah yang mereka hubungkan dengan pesta kejatuhan. Pada musim dingin ada hari yang panjang untuk berpuasa sebagai pengganti waktu tujuh orang yang tidur di dalam gua (Ashhabul Kahfi).

\section{Pokok-Pokok Pemikiran Ikhwan al-Shafa}

Memperha kan kandungan Rasa'ilnya, sebagaimana dikemukakan di atas, pemikiran Ikhwan al-Shafa begituluas dan berasal dari berbagai sumber

Ulul Albab, Vol. 8 No. 2, 2007 
yang sangat beragam. Pemikirannya menembus batasan primordial; sektarian (mazhab), keagamaan, atau kebangsaan. Ikhwan al-Shafa menyebut dirinya sebagai pembawa the primordial tradition dan the philosophy of perennis yang oleh Suhrawardi disebut sebagai al-Hikmat al-Laduniyah (Nasr, 1978:31. 33).

Dengan melacak sumber-sumber Rasa'il, terlihat bahwa pemikiran kosmologinya berasal dari Phitagorean dan Jabirian. Di sini Ikhwan al-Shafa mengaku pengikut Phitagorean dan Nichomacus, terutama dalam penggunaan bilangan sebagai kunci memahami alam, dan interpretasi simbolik dan metafisik terhadap aritmatika dan geometri. Ikhwan al-Shafa menyamakan Phitagorean dan Harranian, yang dengan keduanya Ikhwan al-Shafa memiliki banyak persamaan. Bahkan, Jabir sendiri mengaku tidak hanya memiliki pengetahuan mengenai kebijakasanaan Yunani, juga kebijaksanaan Yamaniah Kuna, yang dipelajarinya dari Harbi Himyatiyyah, dan telah berkenalan dengan sains-sains Hindus. Maka, tidak diragukan, kelompok Jabirian memiliki sumber-sumber dari Phitagorean dan Hermetik, sebagaimana sumber-sumber dari Persia, India, dan bahkan Cina. Oleh karena itu, sumber-sumber Jabirian menjadi sumber-sumber pemikiran Ikhwan al-Shafa.

Dalam Rasa'il, ada pengaruh Phitagrean-Hermetik berkaitan dengan doktrin-doktrin serta praktik-praktik Harranian, dan dalam beberapa hal ada pengaruh filsafat peripatetik, namun tidak dipandang dari sudut pandang sillogistik. Ada pula pengaruh Persia dan India dalam geografi, ekologi, musik, dan linguistik, mengikuti tradisi Ibnul Muqaffa' dan al-Jahiz. Terakhir, ada pula pengaruh al-Qur'an, yang mencakup semua pandangan kelompok para pemikir ini. Ikhwan al-Shafa, misalnya, menafsikan bagian-bagian kosmologi kona dengan istilah-istilah al-Qur'an, seperti al-kursi, al-arsy, dan menjadikannya sebagai tujuan tetap ilmu malakut (Angelology). Islam yang bedasarkan al-Qur'an. Disamping sumber-sumber yang berupa teks, pemikiran Ikhwan al-Shafa bersumber pula pada wahyu dan alam sebagai tambahan. Ikhwan al-Shafa menyatakan pemikirannnya berdasarkan empat buku,yaitu: pertama, matematika dan ilmuaamiah dari perenungan dan 
filosof, kedua, kitab suci Taurat, bibel, dan al-Qur'an, serta catatan -catatan (mushhaf) yang dibawa para nabi mmelalui wahyu malaikat; ketiga, bukubuku tentang alam (nature) adalah ide-ide palatonik; dan keempat, kitabkitab suci (berupa intuisi intelektual) yang hanya diajarkan oleh orangorang suci dan para malaikat yang dekat dengan wujud-wujud tertentu, bangsawan dan jiwa suci (Rasa'il IV:106; Nasr: 39).

Pada bagian ini, penulis akan menyuguhkan dua bidang pemikiran Ikhwan al-Shafa yang terpenting, yaitu filsafat dan kosmologi (bidang pemikiran lainnya, lihat Qodir: 58-64).

\section{Filsafat}

Sebagian besar penggalan di bawah ini diadaptasi dari Nasr (1978:1235). Disebutkan bahwa telah banyak pengamat yang memakaji tujuan Ikhwan al-Shafa menentang situasi politik saat itu dengan mempersiapkan sistem filsafat yang sesuai sebagai basis kehidupan. Sebagian besar dari mereka percaya bahwa tujuannya adalah mengkombinasikan agama dan filsafat. Dalam hal ini, Jalal Huma'i mengungkapkan dua tujuan, yaitu membersihkan syariat dari semua kotoran dengan mengkombinasikannya dengan filsafat; serta menyuguhkan kebenaran-kebanaran esensial filsafat dengan merujuk kepada sumber-sumber kuna (Nasr, 1978:33-8, 39f). Filsafat, bagi Ikhwan al-Shafa, memiliki awal, tengah, dan akhir. Awalnya adalah mencintai ilmu pengetahuan dan mempelajarinya; tengahnya adalah mengenal hakikat segala sesuatu sesuai dengan kadar kemampuan; dan akhir filsafat adalah berbicara dan beramal sesuai dengan ilmu pengetahuan (IAIN Syarif Hidayatullah, 1971:414). Tujuan filsafat dalam pandangannya berbeda dengan filsafat dalam pandangan Ibnu Rusyd atau Thomas Aquinas. Ikhwan al-Shafa memberikan makna yang jauh berbeda dari makna rasionalistik dan sillogistik yang diberikan oleh Aristiteles, yaitu filsafat dalam arti hikmah, bukan human wisdom, melainkan hikmah yang bersumber dari wahyuwahyu yang diberikan kepada nabi-nabi kuno. Ikhwan al-Shafa mengidentifikasi filsafat dengan hikmah (al-Rasa'il, III:324), sebagai bandingan

Ulul Albab, Vol. 8 No. 2, 2007 
terhadap sejumlah penulis muslim terdahulu yangmemaknai filsafat sebagai padanan dari kebijaksanaan manusia yang murni (purely human wisdom). Dan, hikmah sebagai kebijaksanaan yang bersumber di dalam wahyu-wahyu kepada nabi-nabi terdahulu. Lebih jauh, Ikhwan al-Shafa menyebut filsafat sebagai cara mencapai persamaan yang sedekat mungkin dengan Tuhan (the similitude as much as possible of man with $\mathrm{Ged}$ ).

Penggunaan filsafat adalah untuk memperoleh kebajikan manusiawi, yakni mengaktualisasikan semua ilmu pengetahuan yang dimiliki manusia secara potensial. Dengan filsafat, manusia merealisasikan karakteristik kemanusiaannya yang sebenarnya. Manusia, dengan filsafat, mencapai kemanusiaan dan kemajuan dalam hirarki wujud hingga menempuh jalan lurus sampai ke tingkat malakuti (al-Risalah al-Jami'ah, I: 101; Nasr: 34), bahkan meningkatkan derajat manusia yang malakuti di bumi hingga dekat dengan Tuhan (Rasa'il , I: 221). Dari sini, dengan mudah dapat dilihat hubungan antara konsep filsafat Ikhwan al-Shafa ini dengan tujuan filsafat Phitagorean-Socratik dalam rangka memurnikan jiwa manusia, lebih dari sekedar logika perpatetik.

Dalam kaitannya dengan filsafat Islam, Ikhwan al-Shafa menyamakan iman, aspek internal Islam, dengan ibadah ilahiah para filosof (Rasa'il , IV: 301-2). Pembedaan ini sama dengan pembedaan para sufi antara al-Islam, al-Iman, dan al-Ihsan sebagai tiga peringkat as-Sunnah (Tradition), di mana dua yang terakhir bukan saja kepercayaan, melainkan juga kebijaksanaan (wisdom) dan makrifat (gnosis). Bedanya, praktik sufi berkaitan dengan iman dan ihsan, yang secara lengkap diperoleh dari wahyu kepada Nabi Muhammad, sedangkan kebaktian Ikhwan al-Shafa lebih dekat kepada agama keturunan Nabi Idris yaitu Harranian, yang menjadi pewaris OrientalPhitagoreanism di Timur Tengah dan pemelihara serta mendukung Hermetisisme di dunia Islam. Kebaktiannya dilakukan tiga malam dalam sebulan, sebagaimana teah dikemukakan di depan.

Hubungan antara filsafat, kebaktian, dan hikmah mendorong kita untuk menempatkan Ikhwan al-Shafa di dalam garis pewaris Hermetisisme 
dan Neo-Phitagoreanisme, yang melalui Harranian dan Nusairiyah masuk ke dalam Syiah Islam sejak awal sejarahnya.

\section{Kosmologi}

Seluruh dunia, menurut Ikhwan al-Shafa, adalah satu, sebagaimana satu kota, satu hewan, dan satu manusia. Bagian-bagiannya menyatu seperti satu jasad yang hidup yang memperoleh badan dan makanan dari Sabda Tuhan (Divine Word). Bahasa yang dipakai adalah bahasa simbolik, khususnya simbolisme bilangan. Kunci untuk memahami segala sesuatu adalah bilangan. Ikhwan al-Shafa menekankan ciri simbolik dunia, sebagaimana penjelasan "Tuhan menciptakan alam semesta ini nyata (manifest), agar akal dapat memikirkannya. Aspek-aspek alam nyata (alalam al-ajsam) sama dengan yang terdapat dalam alam spiritual (al-alam alarwah). Yang di alam spiritual adalah pengerak, sedangkan yang di alam nyata tergerakkan. Yang di alam spiritual terus ada, sementara yang di alam nyata hilang dan musnah (Rasa'il , II: 232). Di dunia simbol ini, Ikhwan alShafa mempelajari alam semesta dengan maksud memahami kebijaksanaan Tuhan Sang Pencipta. Bagi Ikhwan al-Shafa, kesempurnaan ciptaan menandakan kebijaksanaan dan kesempurnaan Pencipta, kendatipun Dia terhijab dan tidak terlacak indera (Rasa'il , II: 130, 12: 45).

Di antara tipe-tipe simbolisme yang dipakai IS, simbol bilangan merupakan yang paling penting, karena melalui bilangan mereka dapat menghubungkan keanekaragaman (multiplicity) dengan keesaan (unity, Tawhid), dan mengarahkannya kepada harmoni yang meliputi alam semesta. Ilmu bilangan (ilm al-adad) dipandang oleh Ikhwan al-Shafa sebagai cara mememahami keesaan (Rasa'il , I: 173), sebagai ilmu yang berada di atas ilmu lainnya, sebagai obat mujarab pertama dan kimia yang handal. Bahkan, ilmu bilangan adalah emanasi pertama dari akal yang memancar ke jiwa (soul) (Al-Risalah al-Jami'ah, I:28), dan yang mengucapkan tawhid dan transendensi (tanzih) (Al-Risalah al-Jami'ah, I: 30). Tidaklah mengherankan jika Ikhwan al-Shafa selalu memperbandingkan hubungan Tuhan dengan

Ulul Albab, Vol. 8 No. 2, 2007 
alam, atau secara metafisik, Yang Ada (al-Wujud) dengan eksistensi (alMaqujud), seperti halnya bilangan Satu dengan bilangan-bilangan lainnya. Dalam Rasa'il, Ikhwan al-Shafa mengemukakan bahwa Tuhan Sang Pencipta menciptakan sesuatu yang pertama dari yang Esa, sementara Akal Aktif ( al-Aql al-Fa'al) sebagai angka 2 diturunkan dari Satu sebagai pengulangan. Kemudian Jiwa Universal (al-Nafs al-Kulliyah) diturunkan dari Akal sebagai angka 3, yang ditunkan dengan menambahkan satu kepada 2. Lalu, Materi (al-Hayula) dilahirkan dari gerak Jiwa sebagaimana angka 4 lahir dengan menambahkan satu kepada angka 3. ciptaan lain dilahirkan dari al-Hayula yang keberadaannya dikendalikan oleh Akal dan Jiwa sebagaimana angkaangka lain dilahirkan dari angka 4 yang ditambahkan kepada angka-angka sebelumnya (Rasa'il , I: 28-9; Nasr: 46, 12f). dalam Al-Risalah al-Jami'ah, alWujud dihubungkan dengan Satu, sedangkan esensi ketuhanan dengan Nol).

\section{Hirarki Wujud}

Penciptaan alam oleh Tuhan atau manifestasi yang mawjud oleh yang Wujud, oleh Ikhwan al-Shafa dibandingkan dengan penurunan bilanganbilangan dari Satu. Setelah membagi semua yang mawjud menjadi partikular dan general, Ikhwan al-Shafa membagi lebih lanjut, yang General menjadi sembilan bentuk mawjud (state of being), karena sembilan, nilai terakhir dari siklus desimal, menutup siklus itu, dan secara simbolis membawa kepada akhir seri bilangan. Penciptaan alam semesta mulai dari sang pencipta, menurunkan berbagai macam mawjud, dan diakhiri dengan ciptaan terestrial yang mata rantainya berakhir pada manusia, digambarkan sebagai berikut:

1. Pencipta-yang Satu, sederhana, kekal, dan abadi.

2. Akal-yang turunan (innate) dan yang diperoleh (aqquired).

3. Jiwa-meliputi tiga macam: vegetatif, hewani, dan rasional.

4. Al-Hayula (Matter) mencakup empat macam: artifak, fisik, universal, dan original. 
5. Alam (thabi'ah, nature)—ada lima macam: celestial, dan empat unsur alam.

6. Al-Jism (Body) - yang mempunyai enam arah: atas dan bawah, depan dan belakang, kiri dan kanan.

7. Bumi (Sphere)-dengan tujuh pelanetnya.

8. Unsur-unsur-yang memiliki delapan kualitas. Unsur-unsur tersebut dalam realitas adalah empat kualitas yang memecah dua, yaitu:

- Tanah-dingin dan kering;

- Air-dingin dan basah;

- Udara-dingin dan basah;

- Api-panas dan kering.

9. Wujud dunia ini-yang berupa mineral, pepohonan, hewan, yang masing-masing punya tiga bagian.

Wujud yang pertama sampai dengan keempat bersifat universalbilangan 1 sampai 4 mencakup semua bilangan, karena $1+2+3+4=10$, sedangkan wujud lainnya bergabung (berdasarkan pandangan ini, Ikhwan al-Shafa, di tempat lain dalam Rasa'il membagi wujud menjadiempat: Tuhan, Akal Universal, Jiwa Universal, dan al-Hayula.

\section{Akal Universal dan Jiwa Universal}

Akal Universal dan Jiwa Universal, yang posisinya nomor 2 dan angka 3 di bawah Sang Pencipta di dalam hirarki wujud, keduanya berperan di dalam keseluruhan alam semesta; meripakan dualitas, yang di atasnya segala sesuatu (alam) dibangun dan kembali dengan cara-cara tertentu.

Banyak orang berpandangan bahwa alam diciptakan berupa bentuk dan materi, terang dan gelap, substansi dan aksidensi, jiwa dan raga, Kitab Suci (al-Lawh al-Mahfuzh, Guarded Tablet) dan Pena, ekspansi dan kontradiksi, cinta dan benci, sekarang dan yang akan datang, sebab dan akibat, awal dan akhir, luar dan dalam, tinggi dan rendah, berat dan ringan

Ulul Albab, Vol. 8 No. 2, 2007 
(Al-Risalah al-Jami'ah, II: 7-8). Namun, menurut Ikhwan al-Shafa, pada prinsipnya semua itu sama; hanya berbeda dalam aspek sekunder dan dalam ekspresi. Dalam semua kasus, dualitas tersebut menunjuk kepada Akal dan Jiwa yang mengandung dasar-dasar aktif dan pasif, melalui mana kehidupan dan aktivitas alam semesta dapat dimengerti. Ciptaan adalah aspek ketuhanan yang 'dinamis dan feminin'. Ciptaan itu sendiri memiliki aspek 'aktif dan maskulin' yang disebut alam (nature) dan yang merupakan sumber semua aktivitas di alam semesta; serta aspek 'pasif dan feminin' yang bagi kita tampak sebagai 'materi atau dasar bagian dalam' (innate) aktivitas tersebut.

Dalam rangkaian sebab akibat, Akal dapat dibilang hanya memiliki penyebab efisien, yaitu Tuhan. Berkaitan dengan Tuhan, Akal benar-benar pasif, tunduk, ajeg, dan tatap berharap bersatu dengan Tuhan (Divine Principle). Oleh karena Akal adalah wujud tertinggi di alam semesta, maka kepasifannya merupakan simbol kepasifan alam semesta seluruhnya dalam hubungannya dengan Sang Pencipta. Alam semesta hanya menerima, sementara hanyalah memberi (Rasa'il , III: 187f).

Jiwa Universal sebaliknya bertindak pasif dan seperti materi kepada Akal yang aktif kepadanya. Ini hanya memiliki dua sebab, yaitu sebab efisien adalah Tuhan, dan sebab formal adalah Akal (Rasa'il, III: 233). Jiwa Universal menerima dari Akal semua kebajikan, bentuk, dan kualitas positif, dan selanjutnya menyebarkannya ke seluruh alam semesta (Rasa'il, III:235). Jiwa Universal ke selurh alam semesta dan jiwa manusia ke seluruh tubuhnya. Jiwa Universal merupakan penggerak utama (Prime Mover) dunia bintang. Bahkan, semua benda di alam semesta sebagai alat-alat bagi Jiwa Universal untuk bertindak mencapai berbagai tujuan. Semua perubahan di alam semesta, bagaimanapun, diarahkan oleh Jiwa Universal tersebut. Kekuatan-kekuatan Jiwa Universal menjadi 15 bagian: 7 superhuman, 1 human, dan 7 subhuman. Bagian atas bersifat malakur (angelic) dan propetik (kenabian), sedangkan di bawahnya bersifat hewani dan vegetatif (Rasa'il, I: 240). Dalam kosmos yang luas ini, dari langit paling luar, yang melambangkan dunia spiritual dan intelektual, hingga bumi yang paling 
jauh dari langit, yang melambangkan wujud material, bagian-bagian jiwa bergerak menurut tiga macam gerakan:

1. Menjauh dari langit menuju dunia di bawahnya, kaum (generation), Fasad (corruption) hingga ke neraka.

2. Menanjak sampai ke langit.

3. Gerakan horizontal tak mengerti ke mana perginya, seperti dalam jiwa binatang.

Jiwa Universal bertindak melalui tiga saluran: 12 tanda zodiak, langitlangit (aflak), dan planet-planet (al-Risalah al-Jami'ah, I: 313).

\section{Materi (al-Hayula)}

Bagi Ikhwan al-Shafa, al-Hayu la al-Ula (Prime Matter) jauh lebih dahulu terpisah dari Wujud Sebenamya (Pure Being, -Wajib al-Wujad, atau Wujud Pertama) dan hanya memeiliki wujud (eksistensi) dan ketetapan (persistensi). Bagaimanapun, hal ini merupakan prinsip spiritual yang positif, lebih daripada potensialitas. Al-Hayula al-Ula adalah bentuk spiritual yang memancar dari Jiwa Universal (Rasa'il, III: 233). Al-Hayula al-Ula (Primary Matter) dibedakan dari al-Hayula as-Tsaniyah (Secondary Matter). Materi Sekunder menjadi tahapan metafisik pertama terhadap yang kongkret. Sedangkan Materi Primer menjelma bersama Tuhan sebagai Penyebab Efisien. Akal sebagai penyebab formalnya, dan Jiwa Universal sebagai penyebab finalnya. Sebagai penyebab materialnya, Jiwa Universal menjadi penyebab Materi Sekunder itu sendiri, serta menempati substansi tunggal (simple substance) yang memiliki tiga dimensi. Dengan demikian, ada empat penyebab bagi semua anggota yang membentuk Materi Sekunder.

Ikhwan al-Shafa membedakan Materi (al-Hayula) menjadi empat macam:

1. Materi pekerjaan-pekerjaan artifisial (Matter of artificial Works).

2. Mataeri objek-objek alamiah (Matter of natural objects).

Ulul Albab, Vol. 8 No. 2, 2007 
3. Materi Universal (atau Materi Sekunder).

4. Materi Asal (atau Original Matter)

Dijelaskan oleh Ikhwan al-Shafa bahwa materi alamiah meliputi api, udara, air, dan tanah. Semua yang dijumpai di bumi-berupa hewan, tumbuhan, dan mineral-berasal dari unusr-unsur ini, dan jika mengalami kehancuran, akan kembali menjadi materi alamiah tersebut. Pencipta materi-materi alamiah adalah Alam (Nature) itu sendiri, yang merupakan salah satu kekuatan Jiwa Universal.

Materi Universal adalah Badan Absolut (Absolute Body). Dari Badan ini tergambar seluruh badan Alam Semesta, yaitu alam kelestial, bintangbintang, unsur-unsur, dan semua wujud, apa pun rupanya. Semuanya adalah badan-badan yang berbeda hanya dalam bentuknya.

Materi Asal (Original Matter) adalah substansi yang sederhana dan ideal, yang tak dapat diinderai, karena hanya merupakan bentuk eksistensi yang unik, merupakan fondasi awal (primitive foundation, Materi Asal). Jika fondasi ini menerima kuantitas, maka akan menjadi Badan Absolut, dan oleh karena penerimaan itulah ia memiliki tiga dimensi: panjang, lebar, dan tebal. Jika fondasi ini menerima kualitas, seperti bentuk lingkaran, segitiga, atau segi empat, maka ia menjadi badan tertentu, tergantung kepada bentuk apa yang diterimanya. Dengan demikian, kualitas sama dengan 3, kuantitas sama dengan 2, dan fondasi awal sama dengan 1 . seperti halnya 3 datang setelah 2, maka kualitas ada setelah kuantitas, dan seperti 2 datang setelah 1, maka kuantitas datang setelah fondasi awal. Dalam wujudnya, fondasi awal mendahului kuantitas dan kualitas, sebagaimana 1 mendahului 2 dan 3.

Fondasi awal, kuantitas, dan kualitas adalah bentuk-bentuk sederhana (simple) dan ideal yang tidak tertangkap indera. Ketika salah satu bersatu dengan yang lain, maka yang pertama adalah materi, dan yang kedua adalah bentuk. Kualitas adalah bentuk dalam hubungannya dengan kuantitas, dan kuantitas adalah materi bagi kualitas. Pada gilirannya, kuantitas adalah 
bentuk dari fondasi awal (primitive foundation, Materi Asal), dan fondasi awal ini adalah materi bagi kuantitas (Rasa'il, II: 4ff).

Lebih lajut, konsep materi tersebut dapat digambarkan sebagai berikut:

- Materi Asal-tidak memiliki ketergantungan selain kepada Wujud.

- Materi Universal-memiliki kuantitas dan tiga dimensi (Badan Absolut).

- Badan Tertentu (Determined Body)-membentuk kesatuan Badan Absolut yang memerankan materi dan bentuk utama.

Selanjutnya, materi memiliki beberapa tingkatan wujud, masingmasing lebih 'padat' (condensed) dan'beku' (coagulated) dari yang kemudian, mulai dari Materi Pertama atau Materi Asli yang tidak punya kuantitas, dan merupakan bentuk spiritual, dan berakhir dengan materi objek-objek tertentu yang dapat diinderai dan merupakan tahap akhir manifestasi (perwujudan), wujud yang jauh dari Tuhan sebagai prasyarat berlakunya perwujudan kosmik.

Alam (Nature) yang bertindak sebagai penerima tindakan Jiwa Universal adalah salah satu fakultas Jiwa Universal tersebut. Semua yang terjadi di bumi dan di bawah dunia bulan adalah karena Alam, yang menjadi agen, yang mengatur semua perubahan dan merupakan sebab dari semua peristiwa fisika yang disaksikan di sekitar.

\section{Hubungan Tuhan dengan Alam Semesta}

Alam semesta adalah semua wujud material dan spiritual yang menempati langit yang luas, yang merupakan tebaran keanekaragaman yang menyebar ke atmosfer (Sphere), bintang-bintang, unsur-nsur (elements), produk-produknya hingga manusia. Dalam hubungan ini, Ikhwan al-Shafa kadang mengatakan bahwa Tuhan berada di atas yang Wujud (Being), dan terkadang pula, Wujud itu dibagi menjadi Tuhan, dan Alam Semesta. Alam

Ulul Albab, Vol. 8 No. 2, 2007 
semesta ini kadang disebut sebagai sebuah kota atau seekor hewan; namun, sesuatu yang tetap berbeda dengan Tuhan, dihubungkan oleh Tuhan oleh wujudnya, kekekalannya, kelengkapannya, dan kesempurnaannya. Alam dan segala isinya adalah urusan Allah, tidak keluar dari-Nya dan tidak pula menentang perintah-perintah-Nya. Alam ada dalam kekuasaan dan kehendak-Nya. Yang pertama, tertinggi dan terdekat dengan Tuhan adalah Akal, dan Akal adalah seperti hijab agung (al-Hijab al-Azhim) sekaligus pintu gerbang (al-Bab al-Kabir) mencapai keesaan Tuhan (Al-Risalah alJami'ah, II:53; Nasr, 1978:53).

Ikhwan al-Shafa menciptakan simbolisme cinta (isyq) yang dalam istilah sufi menunjukkan atraksi Tuhan dengan alam. Seluruh alam mencari Sang Pencipta dan mencintai-Nya. Sang Pencipta adalah yang tercinta (alMasyuq) dan yang paling diharapkan (al-Murad). Kekuatan rindu dijadikan penyebab utama wujudnya segala sesuatu dan dijadikannya hukum yang mengatur alam. Melalui kerinduan kepada Allah, Akal membawa dunia luar alam, al-Muhith, ke dalam Wujud. Sebaliknya, al-Muhith berputar membentuk dunia di bawahnya, yang prosesnya berlanjut hungga dunia bulan (Nasr, 1978: 54).

\section{Mikrokosmos dalam Hubungannya dengan Alam Semesta}

Anatomi alam semesta dapat dijumpai dalam satu model lengkap; namun, miniaturnya ada pada manusia, yang disebut mikrokosmos. Ini berkenaan dengan filsafat Arab yang menyatakan: al-Insan ramzul wujud, manusia adalah simbol wujud alam semesta. Untuk mewujudkan analogi ini dibutuhkan penjelasan lengkap tentang aspek-aspek kehidupan manusia; sosial, kultural, bahasa, dan bahkan organisasi-organisasi keagamaan, yang semuanya ada persamaannya dengan yang ada di alam semesta.

Aspek diri manusia, seperti fisiknya adalah milik kerajaan hewan, yang mempunyai berbagai keindahan dan cermin kebijaksanaan Pencipta. Dengan menggunakan simbolisme bilangan-dalam arti pengaitan keanekaragaman dengan ke-Esaan-Ikhwan al-Shafa menguraikan 
kebijakasanaan Tuhan dalam menciptakan kerangka manusia dan hewanhewan tertentu, seperti terurai dalam simbol-simbol angka berikut ini:

2 Dia membagi tubuh dalam dua bagian: kiri dan kanan, untuk menghubungkannya dengan bilangan pertama, yaitu 2 .

3 Dia membagi konstitusi hewan ke dalam dua bagian ekstrem, dan bagian pertengahan berkaitan dengan bilangan ganjil pertama, yaitu 3

4 Empat kejenakaan (humorous), yakni bilangan kuadrat pertama.

5 Pancaindera, yakni bilangan bulat (cirkular) pertama.

6 Enam kekuatan gerak di dalam enam arah, yakni bilangan sempurna (tamm) pertama dan bilangan permukaan kubus.

7 Tujuh kekuatan aktif, yakni bilangan sempurna (kamil) pertama, dan jumlah planet.

8 Delapan alam (natures), empat sederhana atau simpel, empat lagi campuran, nilangan kubik pertama dan jumlah not musik.

9 Sembilan tingkatan (thabaqat) tubuh, yakni bilangan kuadrat ganjil pertama dan jumlah langit (heavens).

12. Dua belas pembuka indera dan anggota badan, yalni bilangan tambah pertama $\left(z a^{\prime} i d\right)$ dan jumlah tanda zodiak.

28. Dua puluh delapan hewan bertulang belakang (vertebrata), yakni bilangan sempurna (tamm) kedua, dan jumlah stasiun bulan.

360. Tiga ratus enampuluh pembuluh darah halus (veins), yakni jumlah tingkat-tingkat lingkaran tanda (circle of signs) dan jumlah hari dalam setahun (Rasa'il, II:168-9).

Jika desain tubuh manusia banyak mengambil hewan, maka perbedaan prinsipnya adalah bahwa hanya manusia yang bisa tegak. Posisi vertikal itu melambangkan kanaika ontologis dan metafisik serta kerinduan manusia untuk mencapai dunia spiritual. Sebagaimana kepala manusia yang terpisah dari tubuh, begitu pula upaya mencapai langit. Manusia berdiri dengan kepala

Ulul Albab, Vol. 8 No. 2, 2007 
di atas dan kaki di bawah, sedangkan pohon sebaliknya dengan kepalanya terbenam di tanak dan kakinya menjulang ke langit. Hewan berada pada posisi antara manusia dan tumbuhan, memiliki posisi netral, yaitu arah yang horizontal (Rasa'il, II: 155-6). Perbedaan pokok antara manusia dan hewan tidak banyak pada aspek fisiknya, akan tetapi paa aspek jiwanya. Manusia dapat sama dengan hean seperti halnya dengan langit-langit dengan wilayah Bimasakti (ar-Risalah al-Jami'ah, I: 419).

Ikhwan al-Shafa mengatakan bahwa Tuhan menempatkan segala sesuatu di alam semesta di dalam mikrokosmos. Manusia tidak bisa mengetahui semua hal di alam semesta dengan mengelilingi dan mempelajarinya, karena singkatnya hidup manusia, sementara dunia begitu luas. Hanya dengan mempelajari diri sendirilah manusia dapat memahamai semua hal yang telah ada di dalam dirinya (Rasa'il , III: 9; 12:98).

Tubuh manusia dibangun oleh Pencipta seperti sebuah kota. Unsurunsur anatomisnya menyerupai bebatuan, tembok, peti, pohon, dan metal dalam konstruksi kota. Tubuh tersusun dari bagian-bagian beragam dan mencakup beebrapa sistem biologis seperti bagian-bagian sebuah kota dan bangunan-bangunannya. Anggota-anggota dan organ-organnya dihubungkan dengan tulang sendi seperti jalan raya berhubungan dengan persimpangan-persimpangannya. Jiwa manusia bekerja melalui seluruh tubuh, sebagaimana jin, manusia, hantu, dan malaikat bekerja melalui alam semesta. Sembilan langit (heavens) berkaitan dengan sembilanbagian tubuh: tulang, otak, daging, pembiuluh darah, syaraf, kulit, rambut, dan gigi yang bergeletakan satu di atas yang lain sebagaimana langit-langit; dan 12 tanda zodiak seperti 12 pembuka tubuh: dua mata, hidung, telinga, putting susu, mulut, pusar, dan saluran-saluran pembuangan. Tujuh planet yang mengen dalikan wilayah Bimaksak berkaitan dengan tujuh kekuatan tubuh: a aksi, sensasi, pencernaan (degistion), penolakan (repulsion), nutrisi, tidur, dan imajinasi; serta tujuh kekuatan spiritual: pancaindera, kekuatan biscara, dan fakultas intelektual. Pancaindera berkaitan dengan lima planet yang beredar, kemampuan berbicara dengan bulan, fakultas intelektuan dengan matahari yang menerangi segala sesuatu. Juga seperti bulan menerima cahaya dari

Ulul Albab, Vol. 8 No. 2, 2007 
matahari dan menebarkannya ke 28 rumah besar (mansions) sama dengan kemampuan bicara menerima kekuatan dari faklultas intelektual dan mengirimnya melalui 28 abjad Arab (Nasr, 1978: 100).

\section{Penutup}

Pemikiran Ikhwan mengenai filsafat dan hubungan maknawi dan fungsinya yang selaras dengan agama menginspirasi para pemikir belakangan, termasuk kalangan terpelajar muslim saat ini bahwa tidak proporsional membentuk gagasan dan konsepsi-konsepsi yang mempertentangkan keduanya. Demikian pula pemikiran Ikhwan al-Shafa mengenai kosmologi dan hubungan-hubungan yang terjalin antar berbagai komponen kosmos, menginspirasi gagasan-gagasan dan konsepsi-konsepsi untuk mempertemukan atau membentuk hubungan-hubungan keserasian antara dunia spiritual yang menjadi pusat perhatian para mistisis dan dunia materi yang menjadi fokus perhatian para saintis yang beraliran positivistik. Kedua dunia-spiritual dan material-tidaklah terpisah, melainkan bersifat kontinum, sebagai realitas-realitas yang berujung kepada Allah, sebagai awal dan akhir realitas, sebagaimana disebutkan dalam al-Qur'an: "Dialah yang Awwal dan Akhir; Dia pula yang Zhahir dan Bathin."

Pemikiran Ikhwan al-Shafa ini memperkuat basis ilmiah bagi ilmuan muslim, yang setara dengan penguatan basis filosofis berbagai pemikiran ilmiah. Ilmu pengetahuan, sebagaimana dikenal dalam sejarahnya, berasal dari pemikiran filsafat, dan karenanya filsafat disebut sebagai the mother of sciences. Inilah yang disebut sebagai "dasar tidak ilmiah dari ilmu pengetahuan" ("unscientific base of science"). Banyak kasus dalam sejarah peradaban umat muslim, stagnasi ilmu pengetahuan dipicu oleh stagnasi filsafat, bahkan terdapat episode sejarah yang menunjukkan resistensi tertentu terhadap filsafat, yang kemudian diklaim sebagai penyebab kemuduran peradaban. Filsafat tidak bersentuhan langsung dengan penelitian ilmiah; oleh karena itu sering terabaikan, bahkan dipandang tidak penting oleh sebagian ilmuan. Filsafatlah yang membangun premis- 
premis ilmiah, sekaligus melakukan kritisasi dan validasi pasca penelitian empiris.

\section{DAFTAR PUSTAKA}

Al-Mawsu'ah al-Arabiyah Al-Maysarah. Kairo: 1996.

Brown, Edward G. 1951. A Literari of History of Persia. Jilid I. Cambridge: Cambridge University Press.

Departemen Agama. 1993. Ensiklopedi Islam. Jakarta: Departemen Agama. Fakhry, Majid. 1983. A History of Islamic Philosophy, $2^{\text {nd }}$ Edition. N.Y.: Columbia University Press.

Haitti, Philip K. 1950. History of the Arabs. New York.

IAIN Syarif Hidayatullah. 1971. Ensiklopedi Islam. Jakarta: Djambatan.

Nasr, Seyyed Hossein. 1978. An Introduction to Islamic Cosmological Doctrines. Boulder, Colorado: Shambala Publication Inc.

Qadir, C.A. 1991. Filsafat dan Ilmu Pengetahuan dalam Islam. Terjemahan Hasan Basri. Dari Philosophy and Science in Islamic World (1988). Jakarta: Yayasan Obor.

Tibawi, A.L. 1976. Arabic and Islamic Themes: Historical Education and Literary Studies. London: Luzae and Company Ltd. 